\title{
Smartphones in Order to Measure the Correlation between Speed of Reading and Logical Reasoning of Future Preschool Teachers
}

\author{
https://doi.org/10.3991/ijim.v12i4.9202 \\ David Mendez ${ }^{(\varpi)}$ \\ University Autonoma of Madrid, Madrid, Spain \\ david.mendez@uam.es \\ Antonio Rodríguez, Juan Carlos Sánchez Huete, Gregorio Pérez \\ CES Don Bosco, Madrid, Spain
}

\begin{abstract}
Teacher training is an important key of education, although some authors consider the training is not helpful in order to improve learning science of the future teachers. Understanding scientific and mathematics concepts is necessary to develop the logical or abstract reasoning. Most commonly used, the PISA test is a basis in the scientific and mathematics education. In this research, it measures the logical reasoning with the test of logical reasoning and the reading speed and comprehension have been measured by a science PISA test. The students are 109 years old studying to be kindergarten teachers. They use Socrative and their smartphones in order to answer the questions. The results show that the logical reasoning is in the lowest level, the concrete level. The older students have better results than the younger students and there is a correlation between the reading speed and logical reasoning.
\end{abstract}

Keywords—-smartphone, PISA; science; reading; logical reasoning

\section{$1 \quad$ Introduction}

Educational institutions which have been encouraged to carry out a series of reforms in education, state that professors should stimulate students reasoning, particularly verbal reasoning $[1,2]$. In education, an increasing interest in the development of argumentative competency exists indeed [3]. In fact, this capacity precedes symbolic reasoning, although students' use of symbols as their cognitive development is growing [4]. The tasks, as suggested by the professors, are more open to the students' creativity; they indirectly make easier the capacity to argue. Students do not only have to apply a process, but also to conceive it. This is very common in the learning process based on both research or discovery $[5,6]$.

In the field of science, there are some indications such as their symbolic aspect, which facilitates the interpretation of language construction. The features of this scientific and verbal language are noticed in some aspects regarding the vocabulary, the expression and the psycho-pedagogic implications. Thus, the start must be assumed 
from natural expressions known by the children, using in general terms as basic vocabulary. Since, psycho-educational consequences derived from the grade of precision-abstraction of the issues, exercises and problems that the students are going to find. And, their positive or negative effect regarding comprehension will depend on the verbal level that has been chosen. Therefore, it is essential to choose those words which are more suitable to express concepts [7].

\section{Teacher training}

It is well known that students reveal in numerous signs that they do not understand scientific concepts being unable to apply them in out-of-school contexts. In addition, students use intuitive knowledge about science phenomena that makes very difficult and sometimes impossible to learn scientific concepts. That intuitive knowledge, based on routine activities and superficial thinking, is made of alternative conceptions or preconceptions $[8,9]$. In order to try and remediate this troubling situation, many countries of the European Union (EU) are investing money in science education, introducing new teaching methodologies which promote active learning experiences and taking into account how people learn [10].

To reach this goal, it is necessary to modify the training of the prospective teachers. Special attention should be given to those teachers who will teach science in elementary grades. In general, at these grade levels, students do not have good understanding of science. Most importantly, teaching key concepts to these young pupils will serve as a base for understanding science in next stages [11, 12].

Concerning the contents, most of the prospective elementary teachers do not study science within a four-year period. Therefore, it is difficult that they remember what they have already "learned"; it indicates that they have not understood well enough the key concepts in previous schooling. In addition, they have to study simultaneously different subjects in the same semester.

To add more complications to the situation, some studies report that most of the in-service elementary teachers admit that they try to avoid some science topics due to a lack of confidence at the moment of explaining them [13-15]. In fact, the memories they have of science classes at school are related to textbooks and answers to the questions at the end of every chapter. Nevertheless, there are also a few teachers who enjoy teaching science and do several experiences that are based on the research [11].

Therefore, this lack of a strong theoretical knowledge leads teachers to manage resolution of problematic situations as a routine matter. So, these problematic situations, that appeared in some workbooks or in the chosen course books, differ significantly from their experiences and concerns. Indeed, any occasion of imaginative participation which could arise from the classroom is left on the sidelines. Consequently, motivation which serves to refresh their necessities; and security, which allows the possibility of making a mistake as a means of investigation in the learning process, is dismissed because of the absence of fields with possibilities of creative action [7]. 


\section{Effect of technology}

The use of technology in the classroom and its integration into the curriculum in the form of ICT has had a major impact on schools and the education system as a whole. Developments in computer and communication technologies had an impact on many areas, including education. Internet-based online learning has grown dramatically over the past decade to provide additional training and education for students [16].

One form of technology-enhanced learning environments, called blended learning, combines the Internet with traditional, face-to-face in-class instruction [17]. The availability of digital technologies in their diverse forms (desktop, laptop, tablets, and interactive-whiteboards) is a reality in Spanish and also other European schools [18]; however, a fifth of European teachers believe that using computers in class does not have significant learning benefits for pupils. This holds true especially for Spain $(52 \%)$, Sweden (48\%) and Iceland (47\%). The rejection of change, in the form of ICT use in the classroom has been pointed as one of the reasons [19].

The studies related to the effect of ICT (failed to demonstrate even minimum impact in terms of performance) show some contradictory results. Some research show little or no impact of ICT in the classroom [20,21]. On the contrary, some studies do show a real impact of ICT in the classroom [22]. Fuchs and Woessman [23] used data form PISA and showed that there was a significant correlation between ICT availability and students' performance.

On the other hand, it has been proven that the use of ICTs increases students' motivation for learning, because it gives them more control over their own educational experience [24-26].

For this reason, it is necessary to increase the infrastructure in schools and to develop the knowledge and competences in the use of technological resources amongst teachers. In doing so, teachers can use them effectively to improve the quality in the subject they teach and in management of their classrooms [27].

The advantages of technological resources applied to education are summarized below [28]:

1. They have an influence on student's daily life and are present in informal education.

2. They stimulate communication and offer multiple possibilities of application.

3. They facilitate the development of students' research capacity.

However, the use of ICTs in classroom work does not seem to correspond to the achievements they are attributed [29]. The reasons given for this deferment include the scarcity of technological teacher training. In a study with teachers, Cox, Preston \& Cox [30] concluded that the factors that motivated teachers most in their use of ICTs were: the capacity they perceive they have to use them, the difficulties they come across in their use, the level of the available resources and their satisfaction with them, and whether the use of the technology is considered interesting and entertaining. Teachers and students are increasingly in agreement regarding the utility of ICTs for learning, the acquisition of competences, the development of skills and the com- 
prehension of educational contents [31]. The use of ICTs in classroom activities results in classes that are more active and more participative, producing greater motivation [32-35]. However, some authors also indicate that students prefer not using tablets in class because they are also distractive [36].

At present, the use of mobile technology in classrooms has increased with the growing use of laptops, cell phones and tablets. M-learning is the name given to the type of learning that occurs by means of mobile technological devices, characterized by its ubiquity. Moreover, the definition of mobile learning has passed through different perspectives, ranging from points of view focused on the technology used for learning to the theories conceiving mobile learning as a learning centered on the students, contexts and mobility. For Sharples, Taylor \& Vavoula [37,38], in the era of mobile technology, the process of education is a conversation in a context through and with mobile technology. Learning is mediated by knowledge and technology (is used?) as (an) instrument for productive research, in a situation of mutual support and a relationship that is changing dynamically. These devices offer advantages, such as facilitating cooperative learning experiences, diminishing the formality of learning and helping to increase self-confidence [39].

\subsection{Why do we use smartphones or tablets?}

Manuguerra and Petocz [40] refered to mobile learning (M-learning) as a new concept which has followed E-learning. The use of smartphones and tablets can be very helpful for teachers in tracking and analyzing their student learning and progress in real time. They can also be used as evaluation and assessment tools of both learning and teaching methods.

These are some other benefits of smartphones and tablets:

1. Teachers can easily design a series of knowledge- or opinion- based questions;

2. Students only need their smartphones and Internet access;

3. Teachers know the results of the tests immediately and all at once;

4. The results of the tests do not have to be public. They can only be known to the teacher and a chosen student.

Since smartphones are one of the most commonly used devices, we are going to focus on their integration in a classroom. The advantages are as follows [41, 42]:

1. They can be used to encourage both independent and collaborative learning experiences;

2. They help to remove some of the formality from the learning experience and engage reluctant learners;

3. They help learners remain more focused for longer periods of time;

4. They help to raise self-esteem;

5. They help to combat resistance towards the use of ICTs and can help bridge the gap between mobile phone literacy and ICT literacy;

6. They are low-cost or at no cost to educational institutions;

7. Students use them daily; 
8. They can be used anytime, anywhere, from any source, and at any pace;

9. They can empower students who are visually or hearing impaired;

10. They distract less than laptops.

These technologies are attractive to students and promote motivation [43]. Moreover, in the United States, "93 percent of parents like the idea of an online textbook and 47 percent feel that online textbooks would be a good investment for schools to make to improve student achievement" [44]. The integration of information and communications technologies (ICTs) in the classroom can initially require some extra work and preparation for the teacher; however, long-term advantages are great and eventually result in the saving of time and increased efficiency. For example, there is no need to spend class time teaching students to use new instructional hardware and software [45]. To summarize, it is worth mentioning Prensky here who defined cell phones as "particularly useful computers that fit in your pocket, are always with you, and are always on" [46].

\subsection{What is Socrative?}

There are several student response systems available on market that allow teachers to prepare educational exercises and games via smartphones, laptops, and tablets, test students, and receive immediate feedback and test results, for example, Poll Everywhere, Go Soapbox, and Socrative1 [47]. Socrative has the advantage of being free of charge.

A teacher only needs access to the Internet and a device like laptop, tablet, or smartphone in order to propose some questions and receive the answers of the students. Teachers design activities to do or problems to solve for students in class. They simply log in with their device and interact with the content in real time. Students' responses for multiple-choice and open-ended questions are visually represented on those student response systems. In case of preplanned activities, a teacher can view reports online as a Google spreadsheet or as an Excel file.

These response programs have the following advantages:

1. They neither require any special or expensive software nor electronic device;

2. Devices that are accessible to anyone, such as the Internet and a smartphone with connection to the Internet, are the only prerequisites;

3. They are easy to implement in the classroom.

Regarding strategies of active learning, these tools can facilitate cooperative learning, a methodology that numerous educational institutions are promoting in science education [10]. Moreover, they can be useful to improve understanding of the content explained in class, in particular those that require a lot of repetition, such as arithmetic calculations. A professor only needs to design an activity, give access to it to students, download excel sheets, and check the results. 


\section{The importance of logical reasoning}

As matter of fact, in order to bring students closer to science and mathematics comprehension, academics must know how reasoning processes are necessary for: the comprehension of these concepts, the students' reasoning and the way to improve this former reasoning to facilitate comprehension. Consequently, teachers must expect students' level of knowledge regarding their stage of intellectual development (that is, preoperational, specific, formal, or post-formal) and their knowledge in specific subjects [48].

Thus, in order to favor abstract concepts, the way to develop certain abilities must be found, such as abilities of abstract or logical reasoning. This reasoning, is a creative process which possesses some recognizable elements. Firstly, a confusing observation takes place. Secondly, logical reasoning produces one or more hypothesis. Another possibility as well, might be the use of combinatory reasoning to create a list of every possible combination or hypothesis [49].

Moreover, this reasoning implies a creative thinking; in this way, both the development of the hypothesis and the following process (of which hypothesis is the right one) are facilitated in order to reach the final conclusion. As a result, the development of this ability might be encouraged through a method which provides reasoning, for instance mathematic problems [50].

Ogan-Bekiroglu \& Eskin [51] reached the following conclusions about the relationship between the scientific reasoning and the conceptual knowledge:

1. The quantity and the quality of the students reasoning improved in time.

2. It is possible to predict their quantitative contribution, inspecting their qualitative contribution. Because, if a student make few quantitative contributions, their qualitative contribution will be lower as well, and vice versa.

3. When students are involved in thinking activities, their knowledge does not improve immediately. In other words, the development of knowledge in the reasoning process entails its appropriate quantity of time.

4. Former knowledge affects reasoning involvement. If students are familiarized with the concepts or they have scientific notions about those concepts before starting the reasoning, it is undeniable that they are much more involved in that reasoning and produce new elements.

Problematic qualitative and quantitative situations not only develop curiosity, but also demand reflection, teach how to analyze the results as well as to express them correctly, and they favor a better perception in the relationship between science and technology $[52,53]$. In addition, they facilitate an increase in the involvement, and they promote an improvement in the reasoning of both ideas and opinions, which facilitates access to knowledge.

Formal Reasoning is an important skill not only at the moment of making predictions, but also at the moment of learning science and mathematics. However, it is true that people's former ideas and the use of logical rules of reasoning have a great effect in learning. Moreover, it also exists a partial dependence between the procedures of learning and the conceptual content. Therefore, abstract reasoning is the skill that 
goes beyond the particular case and, that abstract concepts are especially important to learn and understand [54].

The Test of Logical Thinking (TOLT) was used in order to get the measures of abstract reasoning and, it was designed by Tobin and Capie [54]. The TOLT, the Spanish and the original version, has been used in several situations [55]. Acevedo \& Oliva [56] measured the formal reasoning of 1400 students from 13 to 21 years old. Valanides [57] used it with students from 13 to 17 years old. And this test has been used with engineering students [58], chemistry students [59] and pre-service science secondary teachers [60]. Even, there is an experiment with in-service elementary teachers in order to develop the formal reasoning, they used another test of logical thinking, inspired by the TOLT, the GALT [61]. The experiment, was a comparison between the effect in this skill with a group with lab instruction and another with traditional methodology.

According to the level of formal reasoning, there are some different ways of division: the concrete level corresponds to a score from 0 to 3 , the transitional level from 4 to 6 and the formal level from 7 to 10 [62]. Valanides [63] distinguished four levels: concrete (ranges from 0 to 1), transitional (from 2 to 3), formal (from 4 to 7) and rigorous formal (from 8 to 10$)$. And Valanides did another division: concrete ( 0 and 1 ), transitional (2 and 3 ) and formal (from 4 to 10 ).

\section{$5 \quad$ Methodology}

In this research a total of 109 university students aged between 18 and 21 have participated. They are part of three different groups in the Pre-School Education degree (from years first, second and third) with the aim to become future pre-school teachers.

The main objectives of this study are to know students' logical reasoning, to know students' degree of achievement concerning five given dimensions that are assessed through a test on logical reasoning by the TOLT, and to know students' reading speed and understanding on science through a science PISA test [64]. According to the results, the question arises: is there any correlation between the logical reasoning or any of the five dimensions and the reading speed or understanding?

Another objective consists on determining whether or not it is advisable to use technology in the classrooms. For that purpose, students will do a series of tests with smartphones and the Socrative software. In this particular case, a new question arises: Is it possible to get useful information through these devices and complex tests? Should that be the case, these tools would have to be used in the classroom.

\subsection{Instrument}

A TOLT (Test of Logical Thinking) test was used. This multiple-choice test consists on measuring logical reasoning. This ability must be fulfilled with a smartphone and the Socrative software for 40 minutes. This test (TOLT) assesses five reasoning abilities concerning science and provides several and different justification options for 
the answers. It includes two elements for each of the following abilities and reasoning outlines:

- Proportional reasoning: Students' proportional reasoning is a key element to delimit their ability to work and understand the quantitative nature of Mathematics. Those students with problems to reason will consequently find harder to understand equations, functional relations and concepts such as volume and density.

- Probability: It allows students to understand the need to make several attempts in a research, and to use the average of compiled data from similar experiments.

- Control of variables: The process of investigation and control of variables is the most important thinking ability that Mathematics aims to develop. This process is intended to design experimental investigations, students must be able to define, distinguish and manipulate dependent and independent variables. This ability is required in order to understand the movement-time relation.

- Correlative reasoning: Students should have correlative reasoning in order to identify and verify the relationship between variables and problem solving.

- Combinatorial: Students should be able to identify the relationship among the variables of collected data in order to interpret the data according to other variables $[65]$.

Abstract reasoning was measured by the Test of Logical Reasoning (TRL), the Spanish version of TOLT, validated by Acevedo \& Oliva [56].

Concerning reading speed, the instrument used was the PISA [64] science reading understanding test.

\section{$6 \quad$ Results}

The results of abstract reasoning and reading speed are:

Table 1. Average of students' logical reasoning and reading speed

\begin{tabular}{|l|c|c|c|}
\hline \multicolumn{1}{|c|}{ Group } & Students & TOLT & Speed \\
\hline First year & 30 & $2.05 \pm 1.61$ & $192 \pm 52$ \\
\hline Second year & 44 & $2.23 \pm 2.00$ & $202 \pm 64$ \\
\hline Third year & 35 & $2.91 \pm 1.68$ & $229 \pm 47$ \\
\hline
\end{tabular}

Third-year students achieve the best results in reading and logical reasoning, in comparison to the first-year students who achieve the worst. Concerning standard deviation, it might be said that the second-year group has very different results. As it can seen, first and third year groups are a bit more homogeneous.

The results of the five dimensions in the TOLT are shown in Table 2. 
Paper-Smartphones in Order to Measure the Correlation between Speed of Reading and Logical Reas..

Table 2. Results of TOLT five dimensions of future pre-school teachers

\begin{tabular}{|l|c|c|c|c|c|}
\hline \multicolumn{1}{|c|}{ Group } & $\begin{array}{c}\text { Proportional } \\
\text { reasoning }\end{array}$ & Probability & $\begin{array}{c}\text { Control of } \\
\text { variables }\end{array}$ & $\begin{array}{c}\text { Correlative } \\
\text { reasoning }\end{array}$ & $\begin{array}{c}\text { Combina- } \\
\text { torial }\end{array}$ \\
\hline First year & 0.34 & 0.22 & 0.12 & 0.27 & 0.08 \\
\hline Second year & 0.26 & 0.23 & 0.10 & 0.23 & 0.30 \\
\hline Third year & 0.40 & 0.28 & 0.11 & 0.35 & 0.31 \\
\hline
\end{tabular}

First-year group only gets the best results in control of variables although this result is not very significant, while the third-year group achieves the best results in the other four dimensions.

\section{Discussion}

In order to compare the TOLT results, these future pre-school teachers have the concrete level of reasoning according to Tobin \& Capie (1981). The comparison between these students and others is shown in Table 3.

Table 3. Results of TOLT according to age and academic field

\begin{tabular}{|l|c|}
\hline \multicolumn{1}{|c|}{ Groups } & TOLT \\
\hline First year & 2.05 \\
\hline Second year & 2.23 \\
\hline Third year & 2.91 \\
\hline
\end{tabular}

It is very significant that the results of future third-year pre-school teachers are very similar to the 14-15 year-old students. If we compare these results with the Chemistry university students, there is a remarkable difference, 8 to 2.91 .

In Table 4 a comparison between the results of first to third-year pre-school teachers and the dimensions that appear in Oliva's study [62] is shown.

Table 4. Results of TOLT five dimensions concerning future pre-school teachers and 14-15 year-old students

\begin{tabular}{|l|c|c|c|c|c|}
\hline \multicolumn{1}{|c|}{ Groups } & $\begin{array}{c}\text { Proportional } \\
\text { reasoning }\end{array}$ & Probability & $\begin{array}{c}\text { Control of } \\
\text { variables }\end{array}$ & $\begin{array}{c}\text { Correlative } \\
\text { reasoning }\end{array}$ & Combinatorial \\
\hline First year & 0.34 & 0.22 & 0.12 & 0.27 & 0.08 \\
\hline Second year & 0.26 & 0.23 & 0.10 & 0.23 & 0.30 \\
\hline Third year & 0.40 & 0.28 & 0.11 & 0.35 & 0.31 \\
\hline 14-15 years old [62] & 0.29 & 0.38 & 0.13 & 0.26 & 0.37 \\
\hline
\end{tabular}

The youngest students got the best results in probability, control of variables and combinatorial. Third-year students achieved the best results in proportional reasoning and correlative reasoning.

There is a correlation between the TOLT results and reading speed. Better results in TOLT are related to better results in reading speed. 
Paper-Smartphones in Order to Measure the Correlation between Speed of Reading and Logical Reas...

\section{Conclusions}

According to the data obtained, future pre-school teachers have a low level of logical reasoning. They are in the concrete level and obtained similar results to the 14-15 year-old students. Therefore, they will have difficulties understanding and teaching science in the future.

Concerning logical reasoning, the third-year group had the best results compared to the first-year's that had the worst. A correlation is observed between the academic year and the logical reasoning. Moreover, there is a correlation between the reading speed and the academic year and between the reading speed and their logical reasoning. Therefore, the science subjects may have an effect on these dimensions.

It has been proven that the use of smartphones and the Socrative software can help assess these dimensions or give useful information to teachers in the classroom. These technologies might often be used to test if students understand the lesson on a daily basis.

\section{Acknowledgment}

The granted financial support has been provided by CES Don Bosco.

\section{References}

[1] NCTM (2009). Focus in high school mathematics: Reasoning and sense making. National Council of Teachers of Mathematics. Reston, VA. Recovered from: http://www.nctm.org/ [Accessed: 05/03/2012].

[2] COSCE (2011). Informe Enciende. Madrid: Rubes.

[3] Solbes, J., Ruiz, J. J. \& Furió, C. Debates y argumentación en las clases de física y química. Alambique, 63, 65-75, 2010.

[4] Tabach, M., Barkai, R., Tsamir, P.; Tirosh, D., Dreyfus, T. \& Levenson, E. Verbal justification- is it a proof? Secondary school teachers' perceptions. International Journal of Science and Mathematics Education, 8, 1071-1090, 2010. https://doi.org/10.1007/s10763010-9230-7

[5] Etkina, E., \& Van Heuvelen, A. (2004). Investigative science learning environment. Forum on education of the American physical society, spring issue, 12-14, 2004.

[6] Hofstein, A., Kipnis, M., \& Kind, P. (2008). Learning in and from science laboratories: Enhancing students' meta-cognition and argumentation skills. In C. L. Petroselli (Ed.), Science education issues and developments (pp59-94). London: Nova Science.

[7] Sánchez Huete, J. C. \& Fernández Bravo, J. A. La enseñanza de la Matemática. Fundamentos teóricos y bases psicopedagógicas. CCC, Madrid, 2003.

[8] Pozo, J.I., \& Gómez Crespo, M.A. (1998). Aprender y enseñar ciencia (Learn and teach science). Madrid: Morata.

[9] Solbes, J. (2011). ¿Por qué disminuye el alumnado de ciencias? Didáctica de las ciencias experimentales Alambique 67, 53-61.

[10] Eurydice (2011). Science Education in Europe: National Policies, Practices and Research. Bruselas: EACEA. 
Paper-Smartphones in Order to Measure the Correlation between Speed of Reading and Logical Reas...

[11] Avraamidou, L. (2012). Prospective Elementary Teachers' Science Teaching Orientations and Experiences that Impacted their Development. International Journal of Science Education, 1, 1-27.

[12] Avraamidou, L., \& Zembal-Saul, C. (2010). In search of well-started beginning science teachers: Insights from two first year elementary teachers. Journal of Research in Science Education, 47(6), 661-686. https://doi.org/10.1002/tea.20359

[13] Abell, S.K., \& Roth, M. (1992). Constraints to teaching elementary science. A case study of a science enthusiast student. Science Education, 76(6), 581-595. https://doi.org/10.1002/sce.3730760603

[14] Appleton, K., \& Kindt, I. (1999). How do beginning elementary teachers cope with science: Development of pedagogical content knowledge in science. Paper presented at the annual meeting of the national association for research in science teaching, MA, Boston, ERIC, ED448998.

[15] Brickhouse,N.W., Lowery, P., \& Schultz, K. (2000). What kind of a girl does science? The construction of school science identities. Journal of Research in Science Teaching, 37(5), 441-458. https://doi.org/10.1002/(SICI)1098-2736(200005)37:5<441::AID-TEA4>3.0.CO ;2-3

[16] Welsh, E., Wanberg, C., Brown, K. and Simmering, M. (2003). E-learning: Emerging uses, empirical results and futuredirections. International Journal of Training and Development, Vol. 7, No. 4, pp. 245-258. https://doi.org/10.1046/j.1360-3736.2003.00184.x

[17] Osguthorpe, R. T., \& Graham, C. R. (2003). Blended learning environments: definitions and directions. Quarterly Review of Distance Education, 4 (3), 227-233.

[18] Korte, W. B., \& Hüsing, T. (2007). Benchmarking Access and Use of ICT in European Schools 2006: Results from Head Teacher and A Classroom Teacher Surveys in 27European Countries. E-learning Papers. Vol 2, No 1.

[19] Bates, T., Duart, J.M., \& Martinez, M.J. (2004). Gestió del canvi: e-learning como estratègia (Change: e-learning as a strategy). FUOC: Barcelona.

[20] Angrist, J. D., \& Lavy, V. (2002). New Evidence on Classroom Computers and Pupil Learning. Economic Journal 112, 735-765 https://doi.org/10.1111/1468-0297.00068

[21] Goolsbee, A., \& Guryan, J. (2002). The Impact of Internet Subsidies in Public Schools. .NBER Working Paper, 9090. https://doi.org/10.3386/w9090

[22] Sosin, K.; Blecha, B.J.; Agawal, R.; Bartlett, R. 1.; Daniel, J. I. (2004). "Efficiency in the Use of Technology in Economic Education: Some Preliminary Results". American Economic Review. May 2004 (Papers and Proceedings), pp. 253-258 https://doi.org/10.1257/ 0002828041301623

[23] Fuchs, T., \&Woessmann, 1. (2004). Computers and Student Learning: Bivariate and Multivariate Evidence on the Availability and Use of Computers at Home and at School. CESifo Working Paper, 1321.November. Munich.

[24] Condie, R., \& Munro, R. (2007). The impact of ICT in schools: A landscape review. Strathclyde: University of Strathclyde.

[25] Passey, D., Rogers, C., Machell, J., McHugh, G., \& Allaway, D. (2003). The Motivational Effect of ICT on Pupils. London: Department for Education and Skills.

[26] Tally, B. \& Goldenberg, L.B. (2005) Fostering Historical Thinking with Digitalized Primary Sources, Journal of Research on Technology in Education, 38, 1-21. https://doi.org/10.1080/15391523.2005.10782447

[27] Wagner, D., Day, B., James, T., Kozma, R. B., Miller, J. \& Unwin, T. (2005). Monitoring and evaluation of ICT in education projects. A Handbook for Developing Countries. Washington DC: InfoDev/World Bank. 
Paper-Smartphones in Order to Measure the Correlation between Speed of Reading and Logical Reas...

[28] Aguiar, M. V., \& Cuesta, H. (2009). Importancia de trabajar las TIC en Educación Infantil a través de Métodos como las WebQuest (Importance of working through ICT in preschool education with WebQuest). Revista de Medios y Educación, 34, 81-94.

[29] Clares, J., \& Gil, J. (2008). Recursos tecnológicos y metodologías de enseñanza en titulaciones del ámbito de las ciencias de la educación (Technology resources and teaching methodologies in science education degrees). Bordón, 60(3), 21-33.

[30] Cox, M.J., Preston, C., \& Cox, K. (1999). What Motivates Teachers to use ICT?. Paper presented at the British Educational Research Association Conference. Brighton. September.

[31] Edmunds, R., Thorpe, M., \& Conole, G. (2012). Student attitudes towards and use of ICT in course study, work and social activity: A technology acceptance model approach. British Journal of Educational Technology, 43(1), 71-84. https://doi.org/10.1111/j.14678535.2010.01142.x

[32] Méndez, D. (2012). Cambio motivacional realizado por las TIC en los alumnos de secundaria de Física (Motivational change done through ICT with Physics secondary students). Miscelánea de Comillas, 70(136), 199-224.

[33] Méndez, D. (2012). The experience of learning physics through the application of ICT. Energy Education Science and Technology (Part B: Social and Educational Studies), 4(1), 674-679.

[34] Méndez, D. (2013) El aprendizaje cooperativo y la enseñanza tradicional en electricidad y magnetismo en secundaria (Cooperative learning and traditional teaching in electromagnetism in secondary education). Enseñanza de las ciencias, No. extra, 2297-2302.

[35] Méndez, D. (2015). Estudio de las motivaciones de los estudiantes de secundaria de Física y Química y la influencia de las metodologías de enseñanza en su interés (Motivations of secondary students in Physics and Chemistry and the influence of teaching methodologies). Educación XXI, 18 (2), 215-2355, doi: 10.5944/educXX1.14016.

[36] Gokcearslan, S. (2017). Perspectives of students on acceptance of tablets and self-directed learning with technology. Contemporary educational technology, 8 (1), 40-55.

[37] Sharples, M., Taylor, J., \& Vavoula, G. (2005). Towards a theory of mobile learning. In H. van der Merwe \& T. Brown, Mobile technology: The future of learning in your hands, mLearn 2005 Book of Abstracts (p. 58). Cape Town, South Africa: mLearn 2005.

[38] Sharples, M., Taylor, J., \& Vavoula, G. (2007). A Theory of Learning for the Mobile Age. In R. Andrews \& C. Haythornthwaite (eds.), The Sage Handbook of Elearning Research (pp. 221-47). London: Sage. https://doi.org/10.4135/9781848607859.n10

[39] Méndez, D. \& Hargis, J. (2014). The effect of the computers in the learning of formulation with secondary students. Journal of science education, 15 (1), 19-21.

[40] Manuguerra, M., \& Petocz, P. (2011). Promoting student engagement by integrating new technology into tertiary education: The role of the iPad. Asian Social Science, 7(11), 6165. https://doi.org/10.5539/ass.v7n11p61

[41] Eisele-Dyrli, K. (2011). Mobile goes mainstream. District Administration, 47(2), 46-55.

[42] Duncan, D. K., Hoekstra, A. R., \& Wilcox, B. R. (2012). Digital devices, distraction, and student performance: Does in-class cell phone use reduce learning? Astronomy Education Review,11, 1. https://doi.org/10.3847/AER2012011

[43] Méndez, D. \& Slisko, J. (2013). Software Socrative and Smartphones as Tools For Implementation of Basic Processes of Active Physics Learning in Classroom: An Initial Feasibility Study With Prospective Teachers. European Journal of Physics Education, 4 (2), 17 24. 
Paper-Smartphones in Order to Measure the Correlation between Speed of Reading and Logical Reas...

[44] Project Tomorrow. (2010). Creating our future: Students speak up about their vision for 21st century learning. Retrieved October 13, 2012, from http://www.tomorrow.org/ speakup/pdfs/SU09NationalFindingsStudents\&Parents.pdf

[45] Kolb, L. (2011). Adventures with cell phones. Educational Leadership, 68(5), 39-43.

[46] Prensky, M. (2004). What can you learn from a cell phone? Almost anything! Retrieved October 13, 2012, from http://www.marc prensky.com/writing/

[47] Matthew, A. F. (2012). Managing distraction and attention in diverse cohorts: 21st century challenges to law student engagement. Queensland University of Technology Law and Justice Journal, 12(1), 45-65. https://doi.org/10.5204/qutlr.v12i1.229

[48] Lawson, A. E. (2009). The nature and development of scientific reasoning. A synthetic view. International Journal of Science and Mathematics Education, 2 (3), 307-338. https://doi.org/10.1007/s10763-004-3224-2

[49] Hand, B.M., Prain, V., \& Yore, L.D. (2001). Sequential writing tasks' influence on science learning. In P. Tynjala, L. Mason \& K. Lonka (Eds.), Writing as a learning tool: Integrating theory and practice. Dordrecht: Kluwer Academic Publishers. https://doi.org/10.1007/ 978-94-010-0740-5 7

[50] Veerman, A., Andriessen, J. \& Kanselaar, G. (2002). Collaborative argumentation in academic education. Instructional Science, 30, 155-186. https://doi.org/10.1023/A:101510 0631027

[51] Ogan-Bekiroglu, F., \& Eskin, H. (2012). Examination of the relationship between engagement in scientific argumentation and conceptual knowledge. International Journal of Science and Mathematics Education, 10 (6), 1415-1443. https://doi.org/10.1007/s10763012-9346-z

[52] Carrascosa, J.; Gil-Pérez, D.; Vilches, A., \& Valdés, P. (2006). Papel de la actividad experimental en la educación científica (Role of the experimental activity in scientific education). Cuaderno Brasileiro de Ensino de Física, 23, (2), 157-181.

[53] Méndez, D. \& Slisko, J. (2013). The influence of active physics learning on reasoning skills of prospective elementary teachers: A short initial study with ISLE methodology. Latin American Journal of Physics Educantion, 7, 3-9.

[54] Tobin, K. G. \& Capie, W. (1981). The development and validation of a Group Test of Logical Thinking, Educational and Psychological Measurement 41, 413-423. https://doi.org/10.1177/001316448104100220

[55] Souvirón Gaytán de Ayala, P. y Méndez Coca, D. (2015). Desarrollo del pensamiento lógico por medio de la metodología de enseñanza ISLE. Aula de Encuentro, 17, (1), 212-238

[56] Acevedo, J. A., \& Oliva, J. M. (1995). Validación y aplicaciones de un test razonamiento lógico (Validation and aplications of logical reasoning test). Revista de Psicología General y Aplicada, 48, 339-352.

[57] Valanides, N. (1997). Formal reasoning abilities and school achievement, Studies in educational evaluation, 23 (2), 169-185. https://doi.org/10.1016/S0191-491X(97)00011-4

[58] Maris, S. \& Difabio, H. (2009). Academic achievement and formal thought in engineering students. Electronic journal of research in educational psychology, 7 (2), 653-672.

[59] Gupta, T. (2012). Guided-inquiry based laboratory instruction: investigation of critical thinking skills, problem solving skills, and implementing student roles in chemistry. A dissertation for the degree of doctor. Recovered from http://lib.dr.iastate.edu/cgi/ [Accessed: $13 / 05 / 2016]$.

[60] Hackling, M., Garnett, P., \& Dymond, F. (1990). Improving the scientific thinking of preservice secondary science teachers. Australasian journal of teacher education, 15 (2), 2027. 
Paper-Smartphones in Order to Measure the Correlation between Speed of Reading and Logical Reas...

[61] Roadrangka, V., Yeany, R. H., \& Padilla, M. J. (1982). GALT, Group Test of Logical thinking. Athens, GA: University of Georgia.

[62] Oliva, J. (1999). Structural patterns in students' conceptions in mechanics. International Journal of Science Education, 21(9), 903-920. https://doi.org/10.1080/095006999290228

[63] Valanides, N. (1998). Formal operational performance and achievement of lower secondary schools' students, Studies in educational evaluation, 24 (1), 1-23. https://doi.org/10.1016/S0191-491X(98)00001-7

[64] PISA (2013). 5 keys in order to understand mathematic competency in PISA . Recovered from http://blog.educalab.es/inee/2013/12/02/5-claves para-entender-la-competenciamatematica-en-pisa/ [Accessed: 24/02/2016].

[65] Rotter, C.A. Predicting Student's Level of Reasoning Through the TOLT Test. 1999. Recovered from: http://www.as.wvu.edu/phys/rotter/phys201/1 Habits of the Mind/Test of Logic Thinking.html [Accessed: 30/03/2014].

\section{Authors}

David Mendez is with University Autonoma of Madrid, Madrid, Spain.

Antonio Rodríguez, Juan Carlos Sánchez Huete, and Gregorio Pérez are with CES Don Bosco, Madrid, Spain.

Article submitted 20 June 2018. Resubmitted 08 July 2018. Final acceptance 23 July 2018. Final version published as submitted by the authors. 